\title{
Impact of Personality of Company Directors as a Behavioral Risk Contributor on Corporate Governance Process
}

\author{
Muhammad Ahmed.,PhD \\ Faculty of Management Studies, University of Central Punjab \\ muhammadahmad@ucp.edu.pk \\ Saima Naseer \\ Faculty of Management Sciences, University of Central Punjab \\ saimanaseer21@ucp.edu.pk
}

\begin{abstract} aims of the model.

Keywords: Corporate Governance, Behavior, Process, Risk Contributor

\section{Introduction}

Corporate governance as an idea has turned out to be progressively unmistakable because of the event of prominent failures of corporate sector. [1] Some of these failures brought about negative results, for example, occupation and capital misfortunes which influenced the welfare of society monetarily and socially. [2] It ended up plainly imperative, in this way, to expand the attention on corporate governance since it is perceived as a component
\end{abstract}

The purpose behind leading this review is to highlight the behavioral issues with respect to organization directors as a noteworthy contributory variable to the failures subsequent to examining some current and significant failures. The occasions which prompted the corporate failures in organizations, for example, Lehman Brothers, BCCI, Enron, WorldCom, RBS and Maxwell Group represent the improper moves and choices made by the directors and how these decisions added to their failures. The review looks at behavioral risks in corporate governance, and tries to discover behavior constitution. This study suggests that "personality" and "situations" are components which add to behavior. In corporate governance, thought of risk management components shows that the behavioral risks have persisted unidentified to a great extent. Considering the antagonistic financial and social effect of corporate failures in connection to public organizations, which incorporates capital and occupation misfortunes, loss of trust in private enterprise, lessened markets for products and ventures; and the support for the State to intercede keeping in mind the end goal to protect society from the event and results of these failures, this review proposes a hybrid regulatory model to determine impact of personality risks as a major aspect of the corporate governance process.

The basic necessities of a viable risk management process are examined and connected with during the time spent building up a reasonable structure for personality risk management from which the approach and arrangements in the proposed model are drawn. The hybrid model comprises of hard law provisions in the areas where they are deemed most essential in order to create effectiveness and soft law provisions in the areas in which it is thought that flexibility is necessary and would not negate the overall

which adds to the counteractive action of corporate failures [3].An examination of prominent corporate failures which have happened over the most recent two decades delineates that wrong conduct by organization directors added to some of these failures [4]. Organizations are basically overseen by corporate directors, organization directors being the essential officers accommodated under the law ${ }_{[5]}$. In this manner, management works in

The current issue and full text archive of this journal is available at www.jraspublications.org/index.php/JRAS/issue/archive Journal of Research in Administrative Sciences (JRAS)

VII(I), 19-24, ISSN: 2664-2433 
organizations are typically attempted or approved by organization directors and overseeing organizations adequately keeping in mind the end goal to avoid corporate failures is their obligation. Corporate failures can happen for various reasons [6]. Be that as it may, of specific worry in this review are those failures in which a contributory part is the wrong conduct of organization directors. In spite of the various corporate governance changes that have occurred, corporate failures inferable from behavioral issues are as yet happening. In the reports that took after examinations after the $2008 / 2009$ monetary emergency, it was obviously recognized that the conduct of organization directors is an issue in corporate governance [7]. These reports recognized that had been already discussed in earlier years, that behavioral issues related with organization directors were a noteworthy contributory component in some current corporate failures and the subsequent budgetary emergency ${ }_{[8]}$. Behavioral issues can, thusly, be seen as risks to the corporate governance prepare, and these risks are huge in light of the fact that they can possibly bring about corporate failures ${ }^{[9]}$. An investigation of writing demonstrates that two segments, personality and situations, are crucial components in connection to behavior $_{[10]}$. Therefore, if a corporate governance framework does exclude instruments which recognize these parts of behavioral risks, and there are no procedures set up to adequately deal with the risks which collect from each of the segments and which thus make up the totality of what behavioral risks involve, then a gap exists in connection to those unmanaged risks and the framework is imperfect to that degree.

\section{Literature Review}

The review highlights and discusses relevant literature in the areas of corporate governance, corporate risk and risk management, corporate boards and directors, corporate theory, corporate failures, personality and behavior.

\section{Corporate Theory}

The starting point, presence and usefulness of organizations can be clarified by corporate theories [11]. Especially, so as to value the issue highlighted in the review and understand the basis behind the arrangements proposed, and in addition evaluate the reasonableness and viability of these arrangements, it is imperative to discover what organizations are, the means by which they are seen, and empower an understanding of how and why they work the way they do. A talk of corporate theories is in this manner basic to accomplishing these points. Berle and Means ${ }_{[12]}$ had highlighted the organization issues which brought about situations where share proprietorship was scattered and responsibility for enterprise was isolated from control of it. The authoritative theories of the firms have both lawful and financial measurements. The lawful legally binding hypothesis sets that an organization is just the total of at least two people who join so as to embrace business activity.[13] This assumes the organization is established in private contract law as the individuals are associated in the root, demise and existence of the organization by excellence of the agreement which they go into; and one ramifications of this hypothesis is that an organization is a making of individual through and through freedom and along these lines not subject to social responsibility.[14] The monetary authoritative hypothesis depends on the view that free markets are the most effective systems for riches creation. in the concession hypothesis, the State just "has a part to play in guaranteeing that corporate governance structures are reasonable and law based", and the State does not expect to adjust the organization's objectives to its social or political aspirations ${ }_{\text {.[15] }}$ Recently, there has been an expanded thought of interests other than shareholder interests in companies.[16] Therefore, in connection to corporate matters, there are different interests involved ${ }_{[17]}$ If shareholders can't viably secure their advantage or that of others in corporate operations, then "some other arrangement of direction is plainly required".[18]

\section{Corporate Governance}

The Cadbury Committee defined corporate governance as "the system by which companies are directed and controlled" ${ }_{[19]}$

\section{Corporate Board \& Company Directors}

In view of the idea of fuse, an organization is a different lawful entity, yet should essentially "act" through its human agents. ${ }_{[20]}$ Corporate governance instruments have generally centered around the connection between organization directors and shareholders, and stressed the part of the board ${ }_{[21]}$. The (CEO) and management group were depended upon to embrace the duty of authoritative performance. [22] Mace contended that directors were unequipped for applying compelling effect on the organizations they represented on the grounds that their reality was seen as to a greater extent a lawful prerequisite than as beginning from a down to earth require in light of the fact that the management group seemed more responsible for hierarchical affairs ${ }_{[23]}$. Independent of the hypothetical contentions in regards to the exact status of organization directors, or the hypothesis which best clarifies the firm; the reasonable result is that the governing body is saddled with the management of organizations, despite the fact that the directors may not be included in the everyday running of the organization in specific cases. Thus, organization directors are organization specialists doing governance works for the benefit of the organization, the organization being basically its individuals, the shareholders ${ }_{[24]}$.

\section{Corporate Failures}

Corporate governance is worried with the management of organizations so as to accomplish corporate objectives. The most recent two decades have seen broad verbal confrontation on methods for enhancing corporate governance instruments from quarters, for example, governments, scholastics, attorneys, bookkeepers, financial experts, business affiliations and so on. One purpose behind this verbal confrontation is the repeat of corporate scandals and failures in many areas of the world. Cases incorporate the corporate crumples of the Bank of Credit and Commerce (BCCI), Maxwell Group, Polly Peck and Barings Bank in the United Kingdom; WorldCom and Enron in the United States; HIH in Australia; and the corporate scandals including Eurotunnel and the Shell Group.[25] As Cadbury highlighted, "corporate governance" as a term wound up noticeably conspicuous at any rate in the United Kingdom after the corporate falls of the mid 1990 's ${ }_{\text {[26] }}$ "Corporate governance changes emerging after corporate breakdown would regularly inspire a progression of measures extending from laws, posting principles and codes of best practices, all in the offered to thwart future events of corporate mishaps".[27] Despite these measures, corporate scandals and failures have persisted ${ }_{[28]} \mathrm{Du}$ Plessis contends that there are similitudes between the corporate governance issues faced off regarding verifiably and those happening in our general public

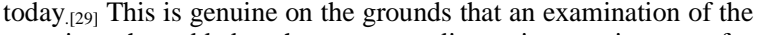
occasions that added to the corporate disappointment in cases, for example, Maxwell, BCCI, HIH, Enron, WorldCom and Lehman Brothers would evoke likenesses in the conduct of the organization directors. In the Maxwell disappointment, there were signs before the crumple of the organization that he was not a man who could be depended on to represent an open company. ${ }_{[30]}$ Lord Bingham in his examination of the BCCI disappointment highlighted the falsifications of organization records broadcasted by the organization directors. ${ }_{[31]}$ The HIH Royal Commission Report shows that the management of the insurance group had covered the genuine condition of the gathering's money related position, a reality which added to its failure ${ }_{[32]}$ In the Enron disappointment, the administrators were blamed for controlling organization accounts among other issues ${ }_{[33]}$ Bernie Ebbers, the WorldCom $\mathrm{CEO}$, was accused of extortion, trick and putting forth false expressions in connection to the organization accounts. [34] $_{\text {The }}$ The Lehman Examiners Report expresses that there are colorable cases against the corporate officers who regulated and guaranteed misdirecting monetary explanations which thusly added to the corporate failure $_{[35]}$ The above cases outline that one of the issues which repeat in corporate breakdown is the improper conduct of organization directors. ${ }_{[36]}$ The OECD highlighted four zones for 
critical activity because of the on-going budgetary emergency and these are corporate risk management, pay and rewards, execution of board directors and shareholder participation ${ }_{[37]}$ The conduct of the top managerial staff was consequently a wellspring of worry in the budgetary emergency. Along these lines, if lessening and aversion of corporate disappointment is wanted, it winds up plainly imperative in corporate governance to examine the linkage between the conduct of organization directors and corporate failures. It is similarly imperative to understand the impact of personality and conduct on corporate governance forms.

\section{Personality and Behavior}

The personality of organization directors is a noteworthy connection to their conduct in the management of organizations.

In connection to behavioral issues in corporate governance, there has been more concentrate on corporate governance structures in late decades and far less concentrate on the conduct of corporate officers who convey these structures to life ${ }_{[38]}$ Bragues contends that regardless of how great the laws might be, despite everything they must be upheld by individuals and if these people are not of sound character, the laws will either be slighted or turned to associate ends. [39] A number with studies have highlighted the need to research the behavioral procedures of organization sheets in an offered to understand the conditions which help compelling corporate governance $_{[40]}$ Organizational culture can likewise effects on behavioral results to the degree that the board can act in ways which adjust to the precepts of the way of life built up inside that association. However, a portion of the activities and choices that have prompted corporate failures were taken by individual directors. It is, accordingly, vital to research the drivers of individual conduct in light of the fact that considering the negative effect of corporate failures on society ${ }_{[41]}$ endeavors made towards enhancing corporate governance components end up plainly imperative. Lee and Phan contend that the choice and assessment of directors ought to be made as far as capabilities that are both nonexclusive to board exercises and particular to worldwide firms.[42] They distinguish some individual characteristics of a successful executive as being nonspecific, and these incorporate quality of character, honesty, sound judgment, marketing prudence. It is similarly vital to examine the connection amongst personality and conduct keeping in mind the end goal to give more learning with respect to the issues and empower an educated approach in connection to creating assessment systems which take perception of those issues. As expressed in section one, the conduct of directors was highlighted as a state of worry in late corporate failures; and thinking about the improper conduct of corporate officers in corporate falls of the mid 1990s and 2000s, it winds up plainly basic to receive a risk perspective of behavioral issues in corporate governance as it is clear that behavioral risks add to corporate disappointment.

\section{Risk Management and Corporate Risk}

Keeping in view the contention that behavioral issues and personality add to corporate failures and, in this way, constitute risks in the corporate governance handle, it is fundamental to understand the significance of risk. It is likewise important to understand what risk management involves as that is crucial in the assurance of arrangements which address saw risks in corporate governance [43]. The cases of corporate failures that have been highlighted and the contributory component of behavioral issues to those failures means that the conduct of organization directors is a risk issue in regard of corporate governance forms. The way that personality adds to behavioral issues places personality as a risk component also in connection to conduct. The essence of the matter then remains whether display corporate governance components are successful in connection to overseeing personality risks and thusly behavioral risks, or whether different choices, for example, direction in such manner would demonstrate more compelling.

\section{Regulatory Theories}

Issues related with behavioral risks and personality in regard of corporate governance forms require that systems are created to deal with those risks if viability is to be accomplished. One of the conceivable choices and the one recommended in this review is administrative intercession. There are different hypotheses with respect to the import of control and how best to accomplish compelling administrative results. It is germane to look at the significant administrative speculations in such manner with a specific end goal to discover alternate points of view and empower an assessment of which administrative methodologies are reasonable and would best accomplish the coveted point. From the development of the organization as a business shape, business pioneers have been supportive of the view that organizations ought to be controlled by business people and not by government authorities, thus the present pattern for the business group to advance delicate law and self-direction in corporate governance.[44] However, from the contentions highlighted above, corporate failures and the effect they have had on society are seen as legitimization for government intervention.[45] Perhaps the imperative issue is to maintain a strategic distance from over direction and to distinguish the ranges of corporate governance which would work all the more viably with statutory regulation.[46] as to managing the choice of corporate officers, Dulewicz and Herbert call attention to that exclusive a minority of designations boards concentrate on descriptors of superior in assessing deputies and conventional techniques for chief determination still prevail.[47] If the point is to enhance corporate governance, then there is a purpose behind the choice procedure to take comprehension of the considerable number of components which would influence an executive's execution. Drew and Kendrick contend that poor corporate governance is a noteworthy wellspring of big business risk [48]. Considering that the personality and conduct of directors are issues which can add to poor corporate governance and in the mission to oversee corporate risks adequately, it is important to receive risk management approaches which would yield the coveted outcomes and this incorporates statutory control.

The investigation of writing in this section especially loans confidence to the real contention in this review which is that the personality of organization directors contributes critical risks to the corporate governance handle, and there is a need to investigate successful methods for moderating these risks.

\section{Conceptual Frame Work}

In this study, hybrid approach is used. This organizational model is appropriate to organization directors. These are the people accused of the management of organizations for the benefit of its shareholders and these shareholders might be on the top managerial staff.

The model illustrates the fundamental issue is the risk related with the personality of these people following up for organizations by making best choices and the related relief of these risks by guaranteeing that the people who oversee organizations add viable governance inside organizations. The goal of the model is to give data which will empower educated decisions as respects the choice of people with proper personalities to take part in corporate governance and additionally to empower risk management related with the determination of people who are not suitable personalities 
for

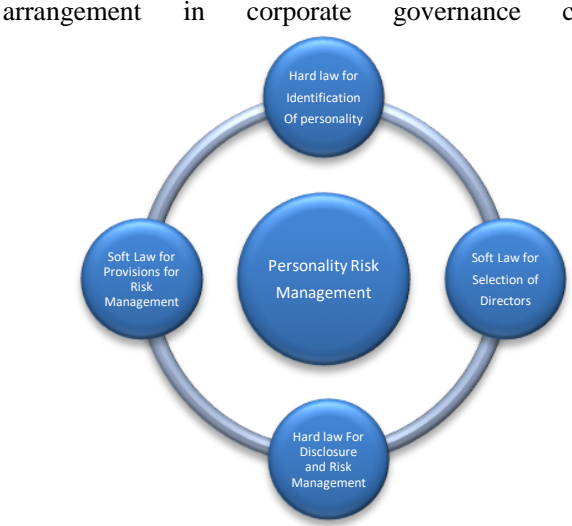

The suggested procedure for the application of the model is as follows:

1) Document issued by State regarding personality risk management:

a) In light of personality research and mental examination, a total and authoritative record should be kept to estimate personality estimations and their effects on corporate governance. Shareholders should have access to this document for consideration in their courses of action..

b) The State should choose to build up an administrative specialist (the outside expert) to manage the assessment of directors for reasons, for example, keeping up comparable standards over all organizations, guaranteeing objectivity, freedom and upgrading powerful observation of the whole procedure. On other side, if the possibilities of an only specialist as supervisor will influence the convenience of the procedure, the State should build up specific prerequisites and standards.

2) Evaluation of directors must be evaluated in relation to their personality dimensions in a public listed company: In view of the personality characteristics, criteria must be set which would decide the difference between generally safe and highly risk dimensions of personality at which an executive can be set dependent upon the consequences of the assessment work out.

3) Selection of directors by shareholders of company:

a) There will be no process for managing personality risk if shareholders chose the directors who come under category of low risk personalities that are appropriate to corporate governance. Moreover, there will be compliance of general standards and laws for further proceedings.

b) Need for compulsory risk management will arise as proposed by this model in the event that directors come under the characterization of personalities not appropriate to corporate governance (high risk directors). Committee established for this purpose including shareholders and executives are liable to answer for their selection as well.

c) There will be arrangement of data with respect to the most proper personality measurements for corporate governance and it will be provided to shareholders so they would settle on levelheaded decisions in the choice of directors. It would be sounder to choose directors who are generally safe since they would be more equipped for proper practices. However, in light of contractual theory, shareholders shouldn't consider aspects of personality for directors they'll choose in future. So under the provision of flexibility proposed by model a chance will be given to high risk directors as well because they're also capable to contribute and avert risks by managing effectually which will result in prevention of corporate failures.

However, it should be noted that shareholders must keep their involvement in process of corporate governance for management of personality risk ensurance.

4) Selected Director's Personality Disclosure: Information concerning the identity chance level ascribed to an official should be revealed to the outside master who is to go about as the managerial expert for the strategy. Shareholders would then be outfitted with the information to help the selection of executives. The chiefs would in like manner approach the information to engage practical hazard administration and by virtue of subsequent courses of action. The details would be uncovered to the Stock Exchange as an element of posting essential and as they are controllers of the offer exchanging framework.

5) General Framework to manage personality risks: Keeping in view different spheres of operations and activities of companies, flexibility for developing their own framework to assess personality risk should be permitted to companies or companies may use framework as a base provided by state. In case of developing their own framework, companies must provide details to external authority for checking accuracy.

In case companies don't adopt framework, state must declare minimum standards to be followed by these companies in regard to personality risk assessment. Adoption for framework is necessary when high risk directors are selected by companies.

\section{Methodology}

This review uses different methodologies because of the way of the examination issue and the recommended arrangements. It is doctrinal and subjective to the degree that the procedure embraced is one which chooses existing appropriate teachings and directions, and also related writing which is most relevant to the examination issue and investigations in connection to the way in which they impact the issue and the degree to which they have given and can give answers for the issue. It utilizes customary doctrinal research strategy by distinguishing and investigating cases and optional lawful materials; and additionally receiving the examination philosophy in the sociologies which creates from a review of pertinent writing. This exploration qualifies as subjective to the degree that it distinguishes an issue which has social ramifications, and creates contentions gone for affecting approach and law change in connection to the examination problem. It is applied research as it examines a circumstance, recognizes an issue and expects to utilize the data inferred to upgrade a superior understanding of the issue and impact arrangement contemplations. It is likewise descriptive and explanatory in the way in which the exploration issue is drawn closer, since it portrays a current circumstance, recognizes a relationship between parts of the issue and looks to proffer clarifications with respect to the issue. The review embraces an unstructured qualitative approach as its essential point is to learn and portray the presence and nature of an issue; break down viewpoints and demeanors encompassing it; utilize subjective factors in conceptualizing the issue and proffered arrangements; and its investigation is gone for building up the variety in the issue without essentially quanitifying it.

\section{Conclusion}

This review distinguishes that behavioral issues can add to corporate failures, and tries to determine how and why that is the situation, and whether any systems exist to check behavioral issues which effect on the viable conveyance of corporate governance. The learning that behavioral issues can constitute issues in regard of the conveyance of viable corporate governance was acquired from dissecting reports issued after examinations concerning corporate failures. Late reports, for example, the Walker Review, the Turner Review and the OECD Reports, and also reports from earlier years, for example, the $\mathrm{HIH}$ report all distinguished behavioral issues as a calculate corporate failures. The review inspected these reports so as to determine how and why behavioral issues added to the corporate failures being referred to. Additionally, an examination of examinations concerning a portion of the major corporate failures which happened over the most recent two decades demonstrated that organization directors acted in particular ways that were viewed as unseemly and which especially added to the corporate failures. A portion of the examinations implied the way that their conduct was intelligent of their personality, concerning occasion in the Maxwell Group case, 
the HIH case, the WorldCom case and the RBS case in which the CEOs were said to be people with overbearing identities. The review then tries to find out what constitutes conduct, and the linkage amongst personality and conduct, with a specific end goal to decide and understand how personality can impact conduct. Once more, it was comprehended that corporate failures have negative outcomes as is clear from the reports and examinations delineating the mischief occasioned to people and society thus of the failures. This implies variables which can possibly bring about corporate disappointment are risky, in light of the fact that an examination of risk writing shows that risk is the potential for an undesirable negative result. For the reason that behavioral issues can prompt corporate failures, it implies that behavioral issues are risk supporters of the corporate governance handle. It likewise implies that the components which constitute conduct would likewise be risk components. In this way, risk management in connection to behavioral risks and its constituent components turns into a vital issue, if corporate failures owing to behavioral issues are to be averted.

This review has received thoughts on personality which were fundamentally settled in the domain of brain research, and transported those thoughts into the domain of corporate governance, as a method for building up an answer for an issue which has been distinguished in regard of corporate governance. Utilizing the information that specific identities are more qualified to conveying successful corporate governance, and certain others constitute higher degrees of risk to the governance procedure, as an apparatus for overseeing risks in corporate governance and anticipating corporate failures is unquestionably a fundamental commitment to the corporate governance writing and would likewise be important in the improvement of arrangement gone for decreasing corporate failures.

This review has addressed its principle investigate suggestion which was to learn whether behavioral issues are risk supporters of the corporate governance prepare and whether behavioral risks and personality risks specifically are recognized and overseen successfully by corporate governance components. It has done as such by looking at and examining corporate failures and brain research writing to verify that personality contributes altogether to conduct; and investigating existing corporate governance components and recognizing that personality risks are not distinguished and overseen successfully by any instrument in corporate governance, and so it can be inferred that behavioral risks are not recognized and overseen viably either on the grounds that personality is a basic component of conduct. So as to find out the methods for overseeing personality risks, an investigation of corporate and administrative speculations is attempted, and in addition an examination of risk management hypotheses and current substances as it identifies with corporate governance, and a mixture administrative model is proposed as a viable way to deal with personality risk management

\section{Recommendations}

Keeping in view the research work done in this study and conclusions made from it a couple of suggestions for future research are promoted. There is a need to study how different traits of personality contribute to process of corporate governance in clear view. Moreover, study must be conducted on various measurements of personality to be fitted in accordance with industry type such as services and manufacturing sector. Yet again, this study has looked into particular personality, yet it is fundamental to discover how this individual personality can impact group personalities in different conditions. In the long run, it is essential to examine in more important aspects the aggregate of contribution of personality in process of corporate governance as concerns of governance includes the human individuals ceaselessly interfacing in view of administration structures keeping the true objective to make happens, appealing once in a while and undesirable in others.

\section{Limitations}

In corporate administration, chiefs have generally been selected through easygoing and self-directing procedures [48]. The assignments admonitory gathering is quite recently required to survey the aptitudes, data and experience required. [49]. It is not essential that directors should change in accordance with a specific personality valuations. Again in association with evaluating executives, it has been demonstrated that chiefs are all around reluctant to experience appraisals in light of the way that the chiefs feel cumbersome at the likelihood of being overviewed and judged $_{[50]}$ It has also been engaged that appraisal results may similarly be dishonest as the method won't not have been finished satisfactorily, profitably and fairly. Identity examinations would deliver comes to fruition which fall under the area of individual information, and in spite of the way that the directors may have agreed to the valuations as an element of the path toward being chosen into process of governance, they may regardless have reservations as for the introduction of this bit of information to shareholders, related board people and controllers.

Notwithstanding the above limitations, the survey gives counter disputes and introduces bolsters for the approach got. In any case, it is imperative to see these repressions and take understanding of the way that the survey deductions which are that properties of personality can be recognized and in like manner risk related with them can be regulated and that authoritative intervention is major and sensible, could be subject to the effect of these limitations.

\section{References}

Preventing Corporate Failure: The Cadbury Committee's Corporate Governance Report' (2003) 10(2) Journal of Financial Crime 141-145. (In the United States, the Enron failure drew enormous attention to corporate governance issues; see the numerous articles relating to the scandal at http://www.businessweek.com/magazine/toc/02_04/B3767enron. htm (accessed 15th June 2012).

See R. Wearing, Cases in Corporate Governance (London: Sage Publications 2005). (Some corporate failures could result in positive outcomes such as the promotion of competition and innovation, as well as the provision of learning opportunities which could enhance the potential for success in other endeavours, )

A.M. Knott \& H.E. Posen, 'Is Failure Good?' (2005) 26(7) Strategic Management Journal 617-641; see also B.

Kirkpatrick, 'The Corporate Governance Lessons from the Financial Crisis' (2009 OECD Financial Market Trends; see also The Turner Review: A Regulatory Response to the Global Banking Crisis, March 2009, at http://www.fsa.gov.uk/pubs/other/turner_review.pdf (accessed 15th June 2012). Ibid, (these reports identify behavioural issues as a contributory element to the corporate failures which led to the financial crisis.)

Hart \& J. Moore, 'Property Rights and the Nature of the Firm' (1990) 98 Journal of Political Economy 1119-1158; see also M.C. Jensen, A Theory of the Firm: Governance, Residual Claims and Organisational Forms (Cambridge, MA: Harvard University Press 2000)

See A. Berle \& G. Means, The Modern Corporation and Private Property (New York: Macmillan 1932)

See S. Bottomley, 'Taking Corporations Seriously: Some Consideration for Corporate Regulation' (1990) 19

Federal Law Review 208.

See D. Sugarman \& G. Rubin (eds.), Law, Economy and Society, 1750-1914 (Abingdon: Professional Books 1984).

See Dine, (note 49) 21. (For instance, the Stakeholder interest theory posits that companies should take cognisance of the interests of stakeholders Developments in Corporate Governance: An Overview' (2006) 12 Journal of Corporate Finance 382; see also 
A.K. Sundaram \& A.C Inkpen, 'The Corporate Objective Revisited' (2004) 15(3) Organisation Science 350-363. Lan \& Heracleous, (note 38) 298.

Dine, (note 49) 35. The Cadbury Report on the Financial Aspects of Corporate Governance published in December 1992, (para 2.5). See s 16 of the United Kingdom Companies Act 2006. The United States has no uniform Companies Act, but see for instance The State of Delaware Code, Title 8 on Corporations, s 106 of which highlights the effects of incorporation and s 107 which states that incorporators shall "manage" the affairs of the company, credence to the fact that companies though legal entities cannot realistically manage themselves.

Corporate governance codes emphasize the role of the board as one of strategic leadership. See A.1 Supporting Principle in the UK Corporate Governance Code 2010.

C.G. Kiel \& G.J. Nicholson, 'Evaluating Boards and Directors' (2005) 13(5) Corporate Governance: An International Review 613-631.

See M.L. Mace, Directors: Myths and Realities (Boston, MA: Harvard University Press 1971)

See s 7 (1) of the UK Companies Act 2006 which provides that a company is formed by one or more persons

subscribing their names to a memorandum and complying with the requirements of the Act as to registration of companies.

See Salacuse, (note 16) 69-83; see also Wearing, (note 2); see also J.G. Hill, 'Regulatory Responses to Global Corporate Scandals' (2005) 23 Wisconsin International Law Journal 367.

See A. Cadbury, 'The Corporate Governance Agenda' (2000), 8(1) Corporate Governance: An International

Review 7-15 at 7 where he stated that "...the subsequent collapse of BCCI Bank, the Maxwell affair and the growing controversy over directors' pay put governance issues on the public agenda for the first time...". See for instance the Cadbury Report (1992) and Codes of Best Practice in the United Kingdom; and also the Sarbanes-Oxley Legislation in the United States. See Young, (note 118); see also T. Clarke, 'Recurring Crises in AngloAmerican Corporate Governance' (2010) 29 Contributions to Political Economy 9-32.

See Du Plessis, (note 50), regarding the behaviour of the company directors in the South Sea bubble; see

http://www.thesouthseabubble.com/ (accessed 15th June 2012) for a modernised commentary on the issue.

See T. Bower, Maxwell: The Outsider (London: BCA 1992) 286287.

Bingham, The Right Honourable Lord Justice, Inquiry into the Supervision of the Bank of Credit and Commerce International, London: HMSO, 1992

See the HIH Royal Commission Report 2003 available at www.hihroyalcom.gov.au/finalreport/index.htm (accessed 15th June 2012).

See B. McLean \& P. Elkind, The Smartest Guys In The Room: The Amazing Rise And Scandalous Fall of Enron (Penguin Group 2003);

See L.W. Jeter, Disconnected: Deceit and Betrayal at WorldCom (New Jersey: Wiley \& Sons 2003); see also

The Financial Times, 4th March 2004, p 28.

See The Lehman Examiners' Report, (note 131) Vol 1, 17 \& 20.

http://lehmanreport.jenner.com/VOLUME\%201.pdf (accessed 15th June 2012).

See R. Tomasic, 'Corporate Governance Failure: The Role of Internal and External Gatekeepers in UK Banks

and Financial Institutions' (2010) 10(1) Corporate Governance:

International Journal for Enhanced Board

Performance 8-11

See the OECD Observer No 273, (note 9).

For instance, the Cadbury Report on the Financial Aspects of Corporate Governance 1992 dealt with issues

such as board structure and composition, board meetings, setting up committees for audit, remuneration,
See G. Bragues, 'The Ancients against the Moderns: Focusing on the Character of Corporate Leaders' (2008)

78 Journal of Business Ethics 373-387 at 375

See E.J. Zajac \& J.D. Westphal, 'Toward a Behavioural Theory of the CEO/Board Relationship: How Research

Can Enhance Our Understanding of Corporate Governance Practices' in D.C. Hambrick, D.A. Nadler \& M.L.

Tushman (eds.), Navigating Change: How CEOs, Top Management Teams and Boards of Directors Steer

Transformation (Cambridge MA: Harvard Business School Press 1998)

41These include job losses, capital ruins, social implications, loos of confidence in capitalism etc. See Bower,

(note 126); see also The FSA Press Release 'Financial Regulation: Learning the Lessons of Maxwell' (2001) at http://www.fsa.gov.uk/Pages/Library/Communication/PR/2001/1 43.shtml (accessed 15th June 2012)

See S. Lee \& P. Phan, 'Competencies of Directors in Global firms-Requirements for Recruitment and

Evaluation' (2000) 8(3) Corporate Governance: An International Review 204-214.

See F.H. Knight, Risk, Uncertainty, and Profit (Boston, MA: Hart, Schaffner \& Marx; Houghton Mifflin Co

1921); chapter three discusses risk in more detail.

See Du Plessis, (note 50) 48 and the reference to DuBois, The English Business Company after the Bubble

Act, (1938) and Carr, Select Charters of Trading Companies AD 1530-1707 (1913)

See Dine, (note 49) 176; see also Musikali, (note 218); Chapter Four discusses corporate failures and their impact on society.

This was also echoed in the EU consultation document on better regulation, (note 204)

See V. Dulewicz \& P. Herbert, 'Current Practice of FTSE 350 Boards Concerning the Appointment, Evaluation

and Development of Directors, Boards and Committees Post the Combined Code' (2008) 4(1) International

Journal of Business Governance and Ethics 99-115.

See Cadbury, (note 225); see also Dulewicz \& Herbert, (note 224)

See the UK Corporate Governance Code 2010, B.2.1 and B.2.2 provisions

See Kazanjian, (note 157) 